DOI: $10.33766 / 2524-0323.88 .56-66$

УДК 343.9

В. М. Саркісян,

аспірант кафедри державно-правових дисциплін

Луганського державного університету внутрішніх справ імені Е. О. Дідоренка

(м. Сєвєродонецьк, Україна)

e-mail: vage3003@gmail.com

iDhttps:/ / orcid.org/0000-0002-7868-9173

\title{
КОНСТИТУЦЙНО-ПРАВОВЕ РЕГУЛЮВАННЯ ГРОМАДСЬКОГО КОНТРОЛЮ ЗА ВИБОРАМИ В УКРАЇНІ
}

У статті розкрито конституційно-правове регулювання громадського контролю за виборами в Україні. Указано, що конституційно-правове регулювання громадського контролю за виборами в Україні здійснюється на двох рівнях - міжнародному та національному. Національний рівень конституційноправового регулювання громадського контролю за виборами в Україні, у свою чергу, містить три підрівні - конституційний, законодавчий та підзаконний, які тісно взаємопов' язані між собою та доповнюють один одного.

Ключові слова: конституційно-правове регулювання, громадський контроль, громадськість, вибори, Україна.

Постановка проблеми. Посилене й зактивізоване здіснення громадського контролю останнім часом поставило питання про надання цій діяльності нормативно-правого та регламентованого характеру. Відтак із кожними новими виборами в Україні конституційно-правове регулювання громадського контролю за цією формою прямого народовладдя набуває більш детального та ускладненого характеру. 3 метою недопущення різного роду зловживань, маніпуляцій чи порушень як збоку громадськості, так і з боку кандидатів, виборчих комісій, інших суб'єктів виборчого процесу та органів публічної влади, необхідно чітко слідувати чинному виборчому законодавствую Принцип «законність - це процедура» має стати одним із основоположних у процесі вдосконалення конституційно-правового регулювання громадського контролю за виборами в Україні.

Аналіз останніх досліджень i публікацій. Питання правового регулювання громадського контролю за діяльністю органів публічної влади в Україні знайшло своє відбиття в працях таких учених, як: І. Журавська [1], В. Кравчук [2], С. Кушнір [3], П. Макушев [4, 5], Т. Наливайко [6], В. Нестерович [7, 8], Л. Рогатіна [9], І. Сердюк [10], В. Федоренко [11, 12] тощо. Водночас, попри наявні наукові праці вказаних учених, питання конституційно-правового регулювання громадського контролю під час проведення виборів в Україні так і не знайшло свого належного дослідження у вітчизняній юридичній науці.

Формування цілей. Метою статті є розкриття конституційно-правового регулювання громадського контролю за виборами в Україні.

Виклад основного матеріалу. Конституційно-правове регулювання громадського контролю за виборами в Україні здійснюється на двох 
рівнях - міжнародному та національному. У федеративних та децентралізованих державах важливу роль у конституційно-правовому регулюванні громадського контролю за виборами відіграє також регіональний та місцевий рівні. Розглянемо та охарактеризуємо кожен рівень конституційно-правового регулювання громадського контролю за виборами в Україні окремо.

1. Міжнароднии рівень конституційно-правового регулювання громадського контролю за виборами передбачає встановлення загальних міжнародних стандартів на основі відповідних передових національних практик демократичних держав різних регіонів світу. Міжнародний рівень конституційно-правового регулювання громадського контролю під час проведення виборів містить як міжнародні договори, які були ратифіковані Верховною Радою України, так і міжнародні документи так званого «м'якого права», які носять рекомендаційний характер, але беруться до уваги національними владними інституціями в нормопроектній та правозастосовній практиці. Наприклад, важливий міжнародний стандарт громадського контролю за виборами закріплений у п. 9 розділу 3 Декларації про критеріївільних і справедливих виборів 1994 року, у якому зазначено, що «кандидат, партія несуть відповідальність перед суспільством. Перш за все, жоден кандидат або політична партія не повинні використовувати насильство» [13]. У розділі III.і Кодексу кращих практик участі громадськості в процесі прийняття рішень 2009 року вказано, що «неурядові організації становлять найважливішу складову процесу участі у відкритому, демократичному суспільстві завдяки залученню великої кількості осіб. Той факт, що багато хто $з$ цих осіб також є виборцями, підкреслює додатковий зв' язок 3 представницькою демократією» [14].

До числа інших міжнародних актів, які визначають загальні міжнародні стандарти здійснення громадського контролю за виборами, слід віднести Загальну декларацію прав людини 1948 року, Конвенцію про захист прав людини та основоположних свобод 1950 року, Міжнародну конвенцію про ліквідацію всіх форм расової дискримінації 1965 року, Документ Копенгагенської наради Конференції з людського виміру ОБСЄ 1990 року, Кодекс належної практики у виборчих справах 2002 року, Конвенцію про стандарти демократичних виборів, виборчих прав і свобод у державахучасницях СНД 2002 року та Конвенщію ООН проти корупції 2003 року.

2. Наиіональний рівень конституційно-правового регулювання громадського контролю за виборами в Україні передбачає встановлення законодавством України відповідних засад, процедур і правил з урахуванням національної правової специфіки проведення виборів та активності й здатності громадськості в здійсненні народовладдя. Національний рівень конституційно-правового регулювання громадського контролю за виборами в Україні містить три підрівні - конституційний, законодавчий та підзаконний, які тісно взаємопов' язані між собою та доповнюють один одного.

Конституція України, хоч і не містить терміна «громадський контроль», але містить низку норм, які визначають конституційні засади для його здійснення за виборами в Україні. 3 огляду на досить велику кількість норм Конституції України, які визначають засади громадського контролю за виборами в Україні, їх слід умовно поділити на три великі групи: 1) конституційні норми, які встановлюють засади народовладдя, верховенства 
права, правового порядку та політичного й суспільного плюралізму; 2) конституційні норми, які визначають засади реалізації громадянами суб'єктивного виборчого права та порядок організації й проведення виборів; 3) конституційні норми, які закріплюють реалізацію конституційних прав і свобод, які є суміжними 3 виборчими правами та дотичними до порядку організації і проведення виборів. У вітчизняній юридичній науці слушно звертається увага, що «норми Конституції України є нормами прямої дії, що, у свою чергу, гарантує громадянам право звертатися до правоохоронних, контрольно-наглядових та судових органів за захистом своїх виборчих прав безпосередньо на підставі норм Конституції України» [15].

У рамках першої групи конституційних норм, які визначають засади громадського контролю за виборами в Україні, Конституція України встановлює, що Україна є демократична та правова держава (ст. 1). Носієм суверенітету і єдиним джерелом влади в Україні є народ, який здійснює владу безпосередньо й через органи державної влади та органи місцевого самоврядування. Ніхто не може узурпувати державну владу (чч. 2, 4 ст. 5). В Україні визнається і діє принцип верховенства права (ч. 1 ст. 8). Суспільне життя в Україні грунтується на засадах політичної, економічної та ідеологічної багатоманітності (ч. 1 ст. 15). Органи державної влади та органи місцевого самоврядування, їх посадові особи зобов'язані діяти лише на підставі, у межах повноважень та в спосіб, що передбачені Конституцією й законами України (ч. 2 ст. 19) [16].

У рамках другої групи конституційних норм, які визначають засади громадського контролю за виборами в Україні, Конституція України встановлює, що народне волевиявлення здійснюється через вибори, референдум та інші форми безпосередньої демократії (ст. 69). Право голосу на виборах і референдумах мають громадяни України, які досягли на день їх проведення вісімнадцяти років. Не мають права голосу громадяни, яких визнано судом недієздатними (ст. 70). Вибори до органів державної влади та органів місцевого самоврядування є вільними і відбуваються на основі загального, рівного і прямого виборчого права шляхом таємного голосування. Виборцям гарантується вільне волевиявлення (ст. 70). Президент України, народні депутати України, депутати Верховної Ради Автономної Республіки Крим, сільські, селищні, міські голови, депутати сільської, селищної, міської, районної, обласної ради, обираються на основі загального, рівного і прямого виборчого права шляхом таємного голосування строком на п'ять років (ч. 1 ст. 76, ч. 1 ст. 103, ч. 1 ст. 136, чч. 1,2 ст. 141). Також Конституція України досить чітко визначає вимоги до Президента України та народних депутатів України, а також порядок та строки проведення в Україні чергових та позачергових виборів (чч. 2, 3 ст. 76, ст. 77, пп. 7, 21, 28, 30 ч. 1 ст. 85, п. 20 ч. 1 ст. 92, чч. 2, 3, 5 ст. 103, п. 7 ч. 1 ст. 106, ч.2 ст. 136, ч. 3 ст. 141) [16].

У рамках третьої групи конституційних норм, які визначають засади громадського контролю за виборами в Україні, Конституція України передбачає, що кожному гарантується право на свободу думки й слова, на вільне вираження своїх поглядів і переконань. Кожен має право вільно збирати, зберігати, використовувати й поширювати інформацію усно, письмово або в інший спосіб - на свій вибір (чч. 1, 2 ст. 34). Громадяни України мають право на 
свободу об'єднання в політичні партії та громадські організації для здійснення й захисту своїх прав і свобод та задоволення політичних, економічних, соціальних, культурних та інших інтересів, за винятком обмежень, встановлених законом в інтересах національної безпеки та громадського порядку, охорони здоров'я населення або захисту прав і свобод інших людей (ч. 1 ст. 36). Громадяни мають право брати участь в управлінні державними справами, вільно обирати й бути обраними до органів державної влади та органів місцевого самоврядування (ч. 1 ст. 38). Громадяни мають право збиратися мирно, без зброї і проводити збори, мітинги, походи й демонстрації, про проведення яких завчасно сповіщаються органи виконавчої влади чи органи місцевого самоврядування (ч. 1 ст. 39). Усі мають право направляти індивідуальні чи колективні письмові звернення або особисто звертатися до органів державної влади, органів місцевого самоврядування та посадових і службових осіб цих органів, що зобов'язані розглянути звернення й дати обгрунтовану відповідь у встановлений законом строк (ст. 40). Кожен має право будь-якими не забороненими законом засобами захищати свої права й свободи від порушень і протиправних посягань (ч. 6 ст. 55) [16].

Законодавчий підрівень регулювання громадського контролю за виборами в Україні є основним рівнем, який регламентує зазначене питання, та містить цілу низку законодавчих актів із різних галузей національного права. Багатомірність законодавчого підрівня регулювання громадського контролю за виборами в Україні обумовлена в першу чергу комплексним характером громадського контролю, який здійснюється за виборами різними суб'єктами через найрізноманітніші форми, які визначені чинним законодавством України, тому в рамках законодавчого підрівня слід виділити три групи законів, які регулюють здійснення громадського контролю за виборами в Україні:

Перша група законів містить норми загальнодекларативного характеру та встановлює необхідність здійснення громадського контролю в Україні, у тому числі й за виборами, а також визнання потреби в здійсненні державою політики щодо посилення ролі громадськості у взаємодії з владою та зміцнення громадянського суспільства. Наприклад, у ч. 1 ст. 5 Закону України № 2411-VI «Про засади внутрішньої і зовнішньої політики» від 1 липня 2010 року передбачено, що основними засадами внутрішньої політики у сфері формування інститутів громадянського суспільства $є$ таке: утвердження громадянського суспільства як гарантії демократичного розвитку держави; завершення політичної реформи, посилення взаємодії органів державної влади й органів місцевого самоврядування та об'єднань громадян, запровадження громадського контролю за діяльністю влади; забезпечення незалежної діяльності об'єднань громадян, посилення їх впливу на прийняття суспільно важливих рішень; підвищення ролі та відповідальності політичних партій, сприяння політичній структуризації суспільства на засадах багатопартійності, створення умов для забезпечення широкого представництва інтересів громадян у представницьких органах влади; проведення регулярних консультацій 3 громадськістю з важливих питань життя суспільства й держави [17].

В іншому Законі України № 1699-VII «Про засади державної антикорупщійної політики в Україні (Антикорупційна стратегія) на 
2014- 2017 роки» від 14 жовтня 2014 року метою формування та реалізації державної антикорупційної політики визначено «створення прозорих засад фінансування проведення виборів, діяльності політичних партій, усунення корупщіогенних ризиків у діяльності виборних органів, посилення громадського контролю за їх діяльністю» (ч. 2 розділу 3). Серед основних заходів, які слід вжити для реалізації державної антикорупщійної політики, визначено таке: ухвалити законодавство щодо посилення громадського контролю за прийняттям рішень виборними посадовими особами, зокрема через запровадження механізму попереднього громадського обговорення суспільно важливих рішень із використанням позитивного вітчизняного досвіду та на основі найкращої світової практики» (п. 5 ч. 3 розділу 3). Основною причиною визначення вказаних мети та заходів у цьому Законі названо те, що «в Україні фактично відсутня чітка законодавча та інституційна основа для формування та реалізащії антикорупційної політики на основі співпраці державних органів та громадськості [18].

Друга група законів визначає порядок здійснення громадського контролю за виборами, виходячи з особливостей здійснення виборчого процесу на виборах в Україні. Мова передусім іде про строки, обмежене коло суб'єктів, які на окремих етапах виборчого процесу можуть здійснювати громадський контроль, форми громадського контролю та питання, щодо яких громадський контроль може здійснюватися під час виборчого процесу. Тому громадський контроль за виборами в Україні в жодному разі не має перешкоджати проведенню в Україні вільних та чесних виборів, які мають відбуватися відповідно до ч. 1 ст. 71 Конституції України, на основі загального, рівного й прямого виборчого права шляхом таємного голосування. До ряду основних законодавчих актів, які визначають порядок здійснення громадського контролю за виборами в Україні, слід віднести закони України «Про вибори Президента України» від 5 березня 1999 року № 474-XIV, «Про вибори народних депутатів України» від 17 листопада 2011 року № 4061-VI, «Про місцеві вибори» від 14 липня 2015 року № 595-VIII, «Про Центральну виборчу комісію» від 30 червня 2004 року № 1932-IV та «Про Державний реєстр виборців» від 22 лютого 2007 року № 698-V [19-23]. Хочеться сподіватися, що в найближчому майбутньому все-таки відбудеться кодифікація виборчого законодавства шляхом прийняття Виборчого кодексу України, різні проекти якого розроблялися впродовж тривалого часу. [24].

Третя група законів закріплює форми, які можуть бути використанні в ході громадського контролю за проведенням виборів в України. Особливість цієї групи законів полягає в тому, що вона місить законодавчі акти з різних сфер суспільного та державного життя, які так чи інакше пов'язані з підготовкою та проведенням виборів в Україні. До ряду основних законодавчих актів, які визначають загальний інструментарій, за допомогою якого здійснюється громадський контроль за виборами в Україні, варто віднести Кодекс України про адміністративні правопорушення, Кримінальний кодекс України, Цивільний кодекс України, Бюджетний кодекс України та закони України «Про інформацію» від 2 жовтня 1992 року № 2657-XII, «Про друковані засоби масової інформації (пресу) в Україні» від 16 листопада 1992 року № 2782-XII, «Про телебачення і радіомовлення» від 21 грудня 1993 року № 3759-XI, «Про 
інформаційні агентства» від 28 лютого 1995 року № 74/95-ВР, «Про звернення громадян» від 2 жовтня 1996 року № 393/96-ВР, «Про порядок висвітлення діяльності органів державної влади та органів місцевого самоврядування в Україні засобами масової інформації» від 23 вересня 1997 року № 539/97-ВР, «Про доступ до публічної інформації» від 13 січня 2011 року № 2939-VI, «Про громадські об'єднання» від 22 березня 2012 року № 4572-VI, «Про Суспільне телебачення і радіомовлення України» від 17 квітня 2014 року № 1227-VII, «Про запобігання корупції» від 14 жовтня 2014 року № 1700-VII, «Про Національну поліцію» від 2 липня 2015 року №580- VIII, «Про судоустрій і статус суддів» від 2 червня 2016 року № 1402- VIII.

Не менш важливе значення в регулюванні громадського контролю за виборами в Україні відіграють підзаконні акти, які деталізують та підсилюють відповідні законодавчі положення в частині більш детального регламентування процедурно-процесуальних засад здійснення громадського контролю за виборами в Україні та визначення стратегічних напрямів подальшого вдосконалення цієї діяльності. Наприклад, у Національній стратегії сприяння розвитку громадянського суспільства в Україні на 2016-2020 роки, яка затверджена Указом Президента України № 68/2016 від 26 лютого 2016 року вказано на дві важливі обставини: 1) Стратегія спирається на базові цінності відносин між демократичною державою й громадянським суспільством, зумовлена становленням такого суспільства як основи народовладдя та прагненням створити належні умови для ефективної взаємодії держави, громадянського суспільства та бізнесу задля модернізації України, підвищення добробуту і створення рівних можливостей для всіх; 2) метою Стратегії $є$ створення сприятливих умов для розвитку громадянського суспільства, налагодження ефективної взаємодії громадськості з органами державної влади, органами місцевого самоврядування на засадах партнерства, забезпечення додаткових можливостей для реалізації та захисту прав і свобод людини й громадянина, задоволення суспільних інтересів із використанням різноманітних форм демократії участі, громадської ініціативи та самоорганізації [25].

До ряду інших підзаконних актів, які так чи інакше регулюють здійснення громадського контролю за виборами в Україні, слід віднести Указ Президента України № 487/2016 «Питання Координаційної ради сприяння розвитку громадянського суспільства» від 4 листопада 2016 року [26], Розпорядження Кабінету Міністрів України № 386-р «Про схвалення Стратегії розвитку інформаційного суспільства в Україні» від 15 травня 2013 року [27], Постанови Центральної виборчої комісії «Про Порядок реєстрації офіційних спостерігачів від іноземних держав, міжнародних організацій на виборах народних депутатів України» від 15 березня 2012 року № 49, «Про Порядок реєстрації офіційних спостерігачів від іноземних держав, міжнародних організацій на виборах Президента України» від 4 березня 2014 року № 30, «Про Порядок реєстрації офіційних спостерігачів від іноземних держав, міжнародних організацій на виборах депутатів Верховної Ради Автономної Республіки Крим, обласних, районних, міських, районних у містах, сільських, селищних рад, сільських, селищних міських голів та старост сіл, селищ» від 28 серпня 2015 року», «Питання діяльності органу (відділу) ведення Державного реєстру виборців та 
регіонального органу (відділу) адміністрування Державного реєстру виборців» від 26 лютого 2016 року № 58, «Про порядок акредитації журналістів, працівників засобів масової інформації при Центральній виборчій комісії» від 31 грудня 2018 року № 275, «Про Роз'яснення щодо порядку надання дозволу громадським організаціям мати офіційних спостерігачів під час позачергових виборів народних депутатів України» від 24 травня 2019 року № 900 тощо.

Висновки. Таким чином, конституційно-правове регулювання громадського контролю за виборами в Україні здійснюється на двох рівнях - міжнародному та національному. Міжнародний рівень конституційно-правового регулювання громадського контролю за виборами передбачає встановлення загальних міжнародних стандартів на основі відповідних передових національних практик демократичних держав різних регіонів світу. Національний рівень конституційноправового регулювання громадського контролю за виборами в Україні містить три niдрівні - конституційний, законодавчий та підзаконний, які тісно взаємопов'язані між собою та доповнюють один одного. Особливість конституційно-правового регулювання громадського контролю за виборами в Україні полягає в тому, що воно грунтується на правових актах, що стосуються різних сфер суспільного та державного життя, які так чи інакше пов'язані з підготовкою та проведенням виборів в Україні.

\section{Використані джерела:}

1. Журавська I. М. Громадський контроль як інтегральна складова у концепті владних відносин сучасної держави і громадянського суспільства. Часопис Київського університету права. 2012. № 3. С. 14-17.

2. Кравчук В. М. Нормативно-правове забезпечення громадського контролю в Україні. Публічне право. 2016. № 2. С. 300-306.

3. Кушнір С. М. Правові засоби громадського контролю в механізмі правового регулювання: автореф. дис. ... канд. юрид. наук: спец. 12.00.01. Запоріжжя, 2011. 20 с.

4. Макушев П. В., Сибіряков С. О. Громадянська та правова культури як соціокультурний фактор у формуванні системи стримувань і противаг в умовах побудови громадянського суспільства. Право і суспільство. 2006. № 3. С.31-37.

5. Макушев П.В., Сибірякова М.В.Шляхи формування антикорупщійної громадянської свідомості як чинник мережевого суспільства. Право і суспільство. 2010. № 3. C.88-96.

6. Наливайко Т. В. Громадський контроль в Україні як інститут громадянського суспільства: теоретико-правовий аспект: автореф. дис. ... канд. юрид. наук : спец. 12.00.01. Львів, 2010. 18 с.

7. Нестерович В. Ф. Предмет і метод виборчого права України. Вісник Луганського державного університету внутрішніх справ імені Е. О. Дідоренка. 2018. № 3. С. 35-42.

8. Нестерович В. Ф. Зміст та структура суб' єктивного виборчого права в Україні. Науковий вісник Дніпропетровського державного університету внутрішніх справ. 2018. Спеціальний випуск № 3. С. 163-169.

9. Рогатіна Л. П. Громадський контроль над державою: сутність, механізми реалізації та перспективи розвитку : автореф. дис. ... канд. політ. наук : спец. 23.00.02. Одеса, 2011. 17 с. 
10. Сердюк I. А. Методологічний аналіз інтерпретацій поняття «громадянське суспільство». Науковий вісник Дніпропетровського державного університету внутрішніх справ. 2014. № 2. С. 49-54.

11. Федоренко В. Л. Кагляк Я. О. Інститути громадянського суспільства та інститут громадських організацій в Україні. Бюлетень Міністерства юстиції України. 2009. № 4-5. С. 75-88.

12. Федоренко В. Л. Конституційне право України: Підручник. К.: Видавництво Лipa-K, 2016. 616 c.

13. Декларация о критериях свободных и справедливых выборов: принята единогласно на 154-й сессии Совета Межпарламентского Союза, Париж, 26 марта 1994 года. INDEM. URL: http://www.indem.ru/idd2000/declaration.htm.

14. Кодекс кращих практик участі громадськості у процесі прийняття рішень: ухвалений Конференцією міжнародних неурядових організацій Ради Свропи на засіданні 1 жовтня 2009 року. Council of Europe. URL: https://rm.coe.int/16802eeddb.

15. Нестерович В. Ф. Поняття та види джерел виборчого права України. Експерт: парадигми юридичних наук і державного управління. 2019. № 2. С. 39-58.

16. Конституція України: прийнята на п'ятій сесії Верховної Ради України 28 червня 1996 року. Відомості Верховної Ради України. 1996. № 30. Ст. 141.

17. Про засади внутрішньої і зовнішньої політики: Закон України від 1 липня 2010 року № 2411-VI . Офіuіийний Вісник України. 2010. № 55. Ст. 1840.

18. Про засади державної антикорупщійної політики в Україні (Антикорупщійна стратегія) на 2014-2017 роки. Відомості Верховної Ради України. 2014. № 46. Ст. 2047

19. Про вибори Президента України: Закон України від 5 березня 1999 року № 474-XIV. Відомості Верховної Ради України. 1999. № 14. Ст. 81.

20. Про вибори народних депутатів України: Закон України від 17 листопада 2011 року № 4061-VI. Відомості Верховної Ради України. 2012. № 10. Ст. 73.

21. Про місцеві вибори: Закон України від 14 липня 2015 року № 595-VIII. Відомості Верховної Ради України. 2015. № 37-38. Ст. 366.

22. Про Центральну виборчу комісію: Закон України від 30 червня 2004 року № 1932-IV. Відомості Верховної Ради Украӥни. 2004. № 36. Ст. 448.

23. Про Державний реєстр виборців: Закон України від 22 лютого 2007 року № 698-V. Відомості Верховної Ради Украйни. 2007. № 20. Ст. 282.

24. Нестерович В. Ф. Проблеми та перспективи прийняття Виборчого кодексу України. Право і суспільство. 2017. № 6. С. 24-29.

25. Національна стратегія сприяння розвитку громадянського суспільства в Україні на 2016 - 2020 роки: затверджена Указом Президента України від 26 лютого 2016 року № 68/2016. Офіиійний вісник України. 2016. № 18. Ст. 716.

26. Про Порядок реєстрації офіційних спостерігачів від іноземних держав, міжнародних організацій на виборах народних депутатів України: Постанова Центральної виборчої комісії 15 березня 2012 року № 49. Верховна Рада Украӥни. URL: https:/ / zakon.rada.gov.ua/laws/show/v0049359-12.

27. Про схвалення Стратегії розвитку інформаційного суспільства в Україні: Розпорядження Кабінету Міністрів України від 15 травня 2013 року № 386-p . Офіціийний Вісник України. 2013. № 44. Ст. 1581.

\section{References:}

1. Zhuravs'ka, I. M. (2012) Hromads'kyy kontrol' yak intehral'na skladova u kontsepti vladnykh vidnosyn suchasnoyi derzhavy i hromadyans'koho suspil'stva. Chasopys Kyyivs'koho universytetu prava - Journal of the Kyiv University of Law, 3, 14-17. [in Ukrainian]. 
2. Kravchuk, V.M. (2016) Normatyvno-pravove zabezpechennya hromads'koho kontrolyu v Ukrayini. Publichne pravo - Public law, 2, 300-306. [in Ukrainian].

3. Kushnir, S. M. (2011) Pravovi zasoby hromads'koho kontrolyu v mekhanizmi pravovoho rehulyuvannya. Extended abstract of candidate's thesis. Zaporizhzhya. [in Ukrainian].

4. Makushev, P. V., Sybiryakov, S. O. (2006) Hromadyans'ka ta pravova kul'tury yak sotsiokul'turnyy faktor $\mathrm{u}$ formuvanni systemy strymuvan' i protyvah $\mathrm{v}$ umovakh pobudovy hromadyans'koho suspil'stva. Pravo i suspil'stvo - Law and society, 3, 31-37. [in Ukrainian].

5. Makushev, P. V., Sybiryakova, M. V. (2010) Shlyakhy formuvannya antykoruptsiynoyi hromadyans'koyi svidomosti yak chynnyk merezhevoho suspil'stva. Pravo i suspil'stvo - Law and society, 3, 88-96. [in Ukrainian].

6. Nalyvayko, T. V. (2010) Hromads'kyy kontrol' v Ukrayini yak instytut hromadyans'koho suspil'stva: teoretyko-pravovyy aspect. Extended abstract of Doctor's thesis. L'viv. [in Ukrainian].

7. Nesterovych, V. F. (2018) Predmet i metod vyborchoho prava Ukrayiny. Visnyk Luhans'koho derzhavnoho universytetu vnutrishnikh sprav imeni E. O. Didorenka - Bulletin of the Luhansk State University of Internal Affairs named after E. O. Didorenko, 3, 35-42. [in Ukrainian].

8. Nesterovych, V. F. (2018) Zmist ta struktura sub"yektyvnoho vyborchoho prava v Ukrayini. Naukovyy visnyk Dnipropetrovs'koho derzhavnoho universytetu vnutrishnikh sprav Scientific Bulletin of Dnipropetrovsk State University of Internal Affairs. Spetsial'nyy vypusk, 3, 163-169. [in Ukrainian].

9. Rohatina, L. P. (2011) Hromads'kyy kontrol' nad derzhavoyu: sutnist', mekhanizmy realizatsiyi ta perspektyvy rozvytku. Extended abstract of Doctor's. Odesa. [in Ukrainian].

10. Serdyuk, I. A. (2014) Metodolohichnyy analiz interpretatsiy ponyattya «hromadyans'ke suspil'stvo». Naukovyy visnyk Dnipropetrovs'koho derzhavnoho universytetu vnutrishnikh sprav - Scientific Bulletin of Dnipropetrovsk State University of Internal Affairs, 2, 49-54. [in Ukrainian].

11. Fedorenko, V. L. Kahlyak, Y. O. (2009) Instytuty hromadyans'koho suspil'stva ta instytut hromads'kykh orhanizatsiy v Ukrayini. Byuleten' Ministerstva yustytsiyi Ukrayiny Bulletin of the Ministry of Justice of Ukraine, 4-5, 75-88. [in Ukrainian].

12. Fedorenko, V. L. (2016) Konstytutsiyne pravo Ukrayiny. K.: Vydavnytstvo Lira-K. [in Ukrainian].

13. Declaration on the criteria for free and fair elections: adopted unanimously at the 154th session of the Council of the Inter-Parliamentary Union, Paris, March 26, 1994 INDEM. URL: http://www.indem.ru/idd2000/declaration.htm. [in Ukrainian].

14. Code of Good Practice for Civil Participation in the Decision-Making Process of 2009. Council of Europe. URL: https:/ / rm.coe.int/16802eeddb. [in Ukrainian].

15. Nesterovych, V. F. (2019) Ponyattya ta vydy dzherel vyborchoho prava Ukrayiny. Ekspert: paradyhmy yurydychnykh nauk $i$ derzhavnoho upravlinnya - Expert: the paradigms of law and public administration, 2, 39-58. [in Ukrainian].

16. Konstytutsiya Ukrayiny: pryynyata na p"yatiy sesiyi Verkhovnoyi Rady Ukrayiny 28 chervnya 1996 roku. (1996) Vidomosti Verkhoonoyi Rady Ukrayiny - Information of the Verkhovna Rada of Ukraine, 30, art. 141. [in Ukrainian].

17. Pro zasady vnutrishn'oyi i zovnishn'oyi polityky: Zakon Ukrayiny vid 1 lypnya 2010 roku № 2411-VI. (2010) Ofitsiinyi visnyk Ukrainy - Official Bulletin of Ukraine, 55, art. 1840. [in Ukrainian]. 
18. Pro zasady derzhavnoyi antykoruptsiynoyi polityky v Ukrayini (Antykoruptsiyna stratehiya) na 2014-2017 roky. (2014) Vidomosti Verkhovnoyi Rady Ukrayiny - Information of the Verkhovna Rada of Ukraine, 46, art. 2047. [in Ukrainian].

19. Pro vybory Prezydenta Ukrayiny: Zakon Ukrayiny vid 5 bereznya 1999 roku № 474-KHIV. (1999) Vidomosti Verkhovnoyi Rady Ukrayiny - Information of the Verkhovna Rada of Ukraine, 14, art. 81. [in Ukrainian].

20. Pro vybory narodnykh deputativ Ukrayiny: Zakon Ukrayiny vid 17 lystopada 2011 roku № 4061-VI. (2012) Vidomosti Verkhovnoyi Rady Ukrayiny - Information of the Verkhovna Rada of Ukraine, 10, art. 73. [in Ukrainian].

21. Pro mistsevi vybory: Zakon Ukrayiny vid 14 lypnya 2015 roku № 595-VIII. (2015) Vidomosti Verkhovnoyi Rady Ukrayiny - Information of the Verkhovna Rada of Ukraine, 37-38, art. 366. [in Ukrainian].

22. Pro Tsentral'nu vyborchu komisiyu: Zakon Ukrayiny vid 30 chervnya 2004 roku № 1932-IV. (2004) Vidomosti Verkhovnoyi Rady Ukrayiny - Information of the Verkhovna Rada of Ukraine, 36, art. 448. [in Ukrainian].

23. Pro Derzhavnyy reyestr vybortsiv: Zakon Ukrayiny vid 22 lyutoho 2007 roku № 698-V. (2007) Vidomosti Verkhovnoyi Rady Ukrayiny - Information of the Verkhovna Rada of Ukraine, 20, art. 282. [in Ukrainian].

24. Nesterovych, V. F. (2017) Problemy ta perspektyvy pryynyattya Vyborchoho kodeksu Ukrayiny. Pravo i suspil'stvo - Law and society, 6, 24-29. [in Ukrainian].

25. Natsional'na stratehiya spryyannya rozvytku hromadyans'koho suspil'stva $\mathrm{v}$ Ukrayini na 2016 - 2020 roky: zatverdzhena Ukazom Prezydenta Ukrayiny vid 26 lyutoho 2016 roku № 68/2016. (2016) Ofitsiinyi visnyk Ukrainy - Official Bulletin of Ukraine, 18, art. 716. [in Ukrainian].

26. Pro Poryadok reyestratsiyi ofitsiynykh sposterihachiv vid inozemnykh derzhav, mizhnarodnykh orhanizatsiy na vyborakh narodnykh deputativ Ukrayiny: Postanova Tsentral'noyi vyborchoyi komisiyi 15 bereznya 2012 roku № 49. (2012) Verkhovna Rada Ukrayiny - The Verkhovna Rada of Ukraine. URL: https:/ / zakon.rada.gov.ua/laws/show/v 0049359-12. [in Ukrainian].

27. Pro skhvalennya Stratehiyi rozvytku informatsiynoho suspil'stva v Ukrayini: Rozporyadzhennya Kabinetu Ministriv Ukrayiny vid 15 travnya 2013 roku № 386-r. (2013). Ofitsiinyi visnyk Ukrainy - Official Bulletin of Ukraine, 44, art. 1581. [in Ukrainian].

Стаття надіӥшла до редколегї 02.11.2019

Саркисян В. М., аспирант кафедры государственно-правовых дисциплин Луганского государственного университета внутренних дел имени Э. А. Дидоренко (г. Северодонецк, Украина)

\section{КОНСТИТУЦИОННО-ПРАВОВОЕ РЕГУЛИРОВАНИЕ ОБЩЕСТВЕННОГО КОНТРОЛЯ ЗА ВЫБОРАМИ В УКРАИНЕ}

В статье раскрыто конституционно-правовое регулирование общественного контроля за выборами в Украине. Указано, что конституционно-правовое регулирование общественного контроля за выборами в Украине осуществляется на двух уровнях международном и национальном. Национальный уровень 
конституционно-правового регулирования общественного контроля за выборами в Украине в свою очередь включает в себя три подуровня - конституционный, законодательный и подзаконный, которые тесно взаимосвязаны между собой и дополняют друг друга.

Ключевые слова: конституционно-правовое регулирование, общественный контроль, общественность, выборы, Украина.

Sarkisyan V.,

Postgraduate student of the Department of State Law Disciplines Lugansk State University of Internal Affairs named after E. O. Didorenko

(Sievierodonetsk, Ukraine)

\section{CONSTITUTIONAL AND LEGAL REGULATION OF PUBLIC CONTROL OVER ELECTIONS IN UKRAINE}

The article describes the constitutional and legal regulation of public control over elections in Ukraine. It is stated that the constitutional and legal regulation of public control over elections in Ukraine is carried out at two levels internationally and nationally. The international level of constitutional regulation of public control over elections implies the establishment of common international standards based on relevant best practices of democratic states in different regions of the world. The international level of constitutional regulation of public control during elections includes both international treaties ratified by the Verkhovna Rada of Ukraine and international soft law documents, which are advisory in nature but are taken into account by national authorities. institutions in norm-design and law-enforcement practice.

The national level of constitutional regulation of public control over elections in Ukraine, in turn, includes three sub-levels - constitutional, legislative and by-law, which are closely interlinked and complementary. It is stated that the Constitution of Ukraine, although it does not contain the term "public control", but includes a number of norms that define the constitutional basis for its implementation in the elections in Ukraine. Given the large number of norms of the Constitution of Ukraine defining the principles of public control over elections in Ukraine, they should be conditionally divided into three large groups: 1) constitutional norms that establish the principles of democracy, the rule of law, the legal order and political and social pluralism; 2) constitutional norms that determine the basis for citizens to exercise subjective suffrage and the procedure for organizing and holding elections; 3) constitutional norms that enshrine the exercise of constitutional rights and freedoms, which are related to the suffrage and are relevant to the procedure for organizing and holding elections.

Ukraine.

Key words: constitutional and legal regulation, public control, public, elections, 